\title{
PENGARUH PROFITABILITAS, FREE CASH FLOW DAN INVESTMENT OPPORTUNITY SET TERHADAP CASH DIVIDEND DENGAN LIKUIDITAS SEBAGAI VARIABEL MODERATING PADA PERUSAHAAN MANUFAKTUR PERIODE 2008 - 2011
}

\author{
Oleh : \\ Elly Susanti \\ Dosen STIE Sultan Agung P. Siantar
}

\begin{abstract}
Abstraksi
Tujuan dari Penelitian ini adalah untuk membuktikan dan menganalisis pengaruh Profitabilitas(diproksikan pada ROI), Free Cash Flow dan Investment Opportunity set (diproksikan pada MVEBVE) baik secara parsial maupun simultan terhadap Cash Dividend pada perusahaan manufaktur yang terdaftar pada Bursa Efek Indonesia, dan juga untuk membuktikan dan menganalisis apakah Likuiditas mampu memoderasi hubungan antara variabel Profitabilitas, Free Cash Flow dan Investment Opportunity set terhadap Cash Dividend. Populasi dari penelitian ini sebanyak 147 perusahaan manufaktur yang terdaftar di Bursa Efek Indonesia (BEI) tahun 2008 - 2011. Sampel diseleksi dengan menggunakan metode purposive sampling sebanyak 32 perusahaan. Untuk hipotesis pertama menggunakan analisis regresi berganda sedangkan untuk hipotesis kedua menggunakan analisis residual. Penelitian ini menunjukkan hasil dari hipotesis pertama Profitabilitas, Free Cash Flow, dan Investment Opportunity Set secara simultan berpengaruh terhadap Cash Dividend. Secara parsial hanya Profitabilitas yang berpengaruh signifikan terhadap Cash Dividend. Selanjutnya Likuiditas digunakan sebagai variabel moderating hasilnya adalah Likuiditas mampu memperkuat hubungan Profitabilitas terhadap pengaruh Cash Dividend dan memperlemah hubungan Free Cash Flow dan Investment Opportunity set terhadap pengaruh Cash Dividend.
\end{abstract}

Kata kunci: Cash Dividend, Profitabilitas, Free Cash Flow, Investment Opportunity set, Likuiditas

Abstraction

The objective of the research was to prove and to analyze the influence of Profitability (ROI), Free Cash Flow, and Investment Opportunity set (MVEBVE), partially and simultaneously on Cash Dividend at the manufacture companies listed in the Indonesia Stock Exchange and to prove and to analyze whether Liquidity (Current Ratio) was able to moderate the correlation of Profitability, Free Cash Flow, and Investment Opportunity set with Cash Dividend. The population was 147 manufacture companies listed in the Indonesia Stock Exchange (BEI) in 2008-2011, and 32 of them were used as the samples which were selected by using purposive sampling technique. Multiple regression analysis was used for the first hypothesis, and residual analysis for the second hypothesis. The result of the first hypothesis showed that Profitability, Free Cash Flow, and Investment Opportunity set, simultaneously, had significant influence on Cash Dividend; but, partially, only Profitability which had significant influence on Cash Dividend. The result of the second hypothesis showed that Liquidity, used as the moderating variable, was able to moderate the correlation of Profitability, Free Cash Flow, and Investment Opportunity set with Cash Dividend at the manufacture companies listed in the Indonesia Stock Exchange.

Keywords: Cash Dividend, Profitability, Free Cash Flow, Investment Opportunity set, Liquidity

\section{A. PENDAHULUAN}

\section{Latar Belakang Masalah}

Para investor umumnya menginginkan pembagian dividen yang relatif stabil, karena dengan stabilitas dividen dapat meningkatkan kepercayaan investor terhadap perusahaan sehingga mengurangi ketidakpastian investor dalam menanamkan modal kedalam perusahaan. Di sisi lain, perusahaan yang akan membagikan dividen dihadapkan pada berbagai macam pertimbangan antara lain perlunya menahan sebagian laba untuk re-investasi yang mungkin lebih menguntungkan, kebutuhan dana perusahaan, likuiditas perusahaan, sifat pemegang saham, target tertentu yang berhubungan dengan rasio pembayaran dividen dan faktor-faktor lain yang berhubungan dengan kebijakan dividen (Sunarto dan Kartika 2003).

Profitabilitas merupakan kemampuan perusahaan memperoleh laba dalam hubungannya dengan penjualan, total aktiva maupun modal sendiri. Dalam penelitian ini peneliti menggunakan Return On Investment (ROI), karena ROI merupakan ukuran efektifitas perusahaan dalam menghasilkan keuntungan dengan memanfaatkan aktiva tetap yang digunakan untuk operasi. Semakin besar ROI menunjukkan kinerja perusahaan yang baik, karena tingkat kembalian investasi (return) semakin besar, sehingga wajar jika pemegang saham mengharapkan pembagian cash dividend jika ROI meningkat. 
Free cash flow dapat menjadi gambaran kinerja suatu perusahaan, perusahaan dengan free cash flow berlebih akan memiliki kinerja yang lebih baik dibandingkan perusahaan lainnya karena perusahaan tersebut dapat memperoleh keuntungan atas berbagai kesempatan yang mungkin tidak dapat diperoleh perusahaan lain.

Investment Opportunity Set dapat diamati dari pertumbuhan nilai buku perusahaan di masa mendatang, sehingga nilai perusahaan di masa mendatang akan tercermin dari harga saham, karena harga saham mencerminkan present value dari arus kas di masa mendatang yang akan diterima investor. Perusahaan-perusahaan yang sedang berkembang membutuhkan dana untuk investasi pada perusahaan, sehingga akan kurang likuid karena dana cenderung diinvestasikan pada aktiva tetap dan aktiva lancar. Dalam penelitian ini peneliti menggunakan Current ratio yang dihitung dengan membagi aktiva lancar (current assets) dengan hutang atau kewajiban lancar (current liability). Semakin besar current ratio menunjukkan semakin tinggi kemampuan perusahaan dalam memenuhi kewajiban jangka pendeknya (termasuk didalamnya kewajiban membayar cash dividend yang terutang), dan juga menunjukkan keyakinan investor terhadap kemampuan perusahaan membayar dividen yang dijanjikan. Penelitian mengenai Cash Dividend telah dilakukan oleh beberapa peneliti terdahulu, tetapi hasil dari penelitian yang dilakukan oleh peneliti terdahulu tidak konsisten.

\section{Rumusan Masalah}

Berdasarkan uraian latar belakang masalah di atas penelitian ini memiliki rumusan masalah sebagai beirkut:

a. Apakah ada pengaruh profitabilitas, free cash flow dan investment opportunity set terhadap cash dividend baik secara parsial maupun secara simultan pada perusahaan manufaktur yang terdaftar di Bursa Efek Indonesia tahun 2008 sampai dengan 2011 ?

b. Apakah likuiditas mampu memperkuat atau memperlemah hubungan antara Profitabilitas, Free Cash Flow dan Investment Opportunity Set terhadap Cash Dividend.

\section{Tujuan Penelitian}

Penelitian ini diharapkan dapat memberikan kontribusi pemikiran kepada penulis sebagai tambahan pengetahuan mengenai pengaruh profitabilitas, free cash flow dan investment opportunity set terhadap cash dividend dengan likuiditas sebagai variabel moderating. Bagi para praktisi penelitian ini diharapkan dapat membantu emiten manajemen perusahaan untuk pengambilan keputusan dalam melakukan pembagian cash dividend. Investor dapat mengetahui faktor-faktor apa saja yang dapat mempengaruhi keputusan emiten dalam pembagian cash dividend. Serta bagi peneliti selanjutnya penelitian ini dapat dijadikan sebagai bahan referensi.

\section{Metode Penelitian}

Desain penelitian yang digunakan adalah penelitian asosiatif, yaitu untuk menganalisis hubungan antara satu variabel dengan variabel lainnya atau bagaimana suatu variabel mempengaruhi variabel lain. Teknik pengambilan sampel yang digunakan oleh penelitian adalah metode purposive sampling. Metode pengumpulan data yang digunakan adalah melalui studi dokumen. Data yang dipakai dalam penelitian ini adalah data sekunder yang diteliti pada situs resmi www.idx.co.id. model teknik analisis data yang digunakan dalam penelitian ini dilakukan dengan pendekatan teknik analisis regresi linier berganda dan uji hipotesis seperti ui t dan uji F untuk hipotesis pertama sedangkan untuk hipotesis kedua menggunakan uji residual.

\section{B. LANDASAN TEORI}

1. Agency Theory dan Kebijakan Dividend

Agency Theory adalah teori yang menjelaskan hubungan agen (agency relationship) dan masalah masalah yang ditimbulkannya (Jensen dan Meckling, 1976).

Sehubungan dengan kebijakan dividen, Brigham \& Houston (2006) menyebutkan ada tiga teori dari preferensi investor yaitu:

a. Dividend irrelevance theory. Miller dan Modigliani (1961) berpendapat nilai suatu perusahaan tidak ditentukan oleh besar kecilnya Dividend Payout Ratio (DPR) tetapi ditentukan oleh laba bersih sebelum pajak (Earnings Before Income Tax - EBIT) dan risiko bisnis.

b. Bird-in the-hand theory, sependapat dengan Gordon dan Lintner yang menyatakan bahwa biaya modal sendiri akan naik jika Dividend Payout Ratio (DPR) rendah. Hal ini dikarenakan investor lebih suka menerima dividen dari pada capital gains.

c. Tax preference theory adalah suatu teori yang menyatakan bahwa karena adanya pajak terhadap keuntungan dividen dan capital gains maka para investor lebih menyukai capital gains karena dapat menunda pembayaran pajak.

Ang (1997) menyatakan bahwa dividen tunai (cash dividend) merupakan dividen yang dibayarkan dalam bentuk uang tunai, sedangkan dividen saham (stock dividend) merupakan dividen yang dibayarkan dalam bentuk saham dengan proporsi tertentu. Menurut Gumanti (2011 : 114 ) Analisis keuntungan (profitabilitas) menunjukkan seberapa mampu perusahan dalam menghasilkan laba, baik dari penjualan yang ada maupun dari aset total yang dimiliki.

\section{Free Cash Flow}

Free cash flow yang berarti arus kas yang benar-benar tersedia untuk didistribusikan kepada seluruh investor (pemegang saham dan pemilik utang) setelah perusahaan menempatkan seluruh investasinya pada aktiva tetap, produk-produk baru, dan modal kerja yang dibutuhkan untuk 
mempertahankan operasi yang sedang berjalan (Brigham \& Houston 2006).

\section{Investment Opportunity Set}

Investment Opportunity Set dipengaruhi oleh seberapa besar hutang yang digunakan dalam struktur modal, karena penggunaan modal saham atau hutang memiliki konsekuensi masing-masing. Penggunaan saham yang terlalu banyak dengan mengabaikan pemanfaatan hutang berdampak pada tingginya kewajiban bagi perusahaan untuk membayarkan cash dividend. Hal ini menyebabkan hilangnya kesempatan bagi perusahaan untuk memanfaatkan laba untuk kepentingan pertumbuhan apabila pemegang saham tidak menghendaki. (Brigham \& Houston 2001).

\section{PEMBAHASAN}

\section{Statistik Deskriptif}

Tabel 2 menunjukkan gambaran mengenai variabel variabel penelitian. Penelitian tersebut menyajikan gambaran mengenai variabel variabel penelitian disajikan dalam tabel statistik deskriptif yang menunjukkan nilai minimum, nilai maksimum, nilai rata rata dan standar deviasi.

Tabel 1

Statistik Deskriptif

\begin{tabular}{|c|c|c|c|c|c|}
\hline & $\mathrm{N}$ & $\underset{\mathrm{m}}{\mathrm{Minimu}}$ & $\begin{array}{c}\text { Maximu } \\
\mathrm{m}\end{array}$ & Mean & $\begin{array}{c}\text { Std. } \\
\text { Deviation }\end{array}$ \\
\hline PRO_X & $\begin{array}{r}12 \\
8\end{array}$ &,- 01 & 1,10 &, 1504 & ,12996 \\
\hline 1 & 8 & & & & \\
\hline FCF_X2 & 96 & 17,94 & 30,00 & 25,8151 & 2,09658 \\
\hline IOS_X3 & $\begin{array}{r}12 \\
8\end{array}$ & ,06 & 38,97 & 2,8562 & 5,20545 \\
\hline LIKUI_ & 12 & ,00 & 11,74 & 3,1014 & 2,16136 \\
\hline M & 8 & & & & \\
\hline CD_Y & 12 & 2,00 & 10500,0 & 741,684 & 1951,660 \\
\hline & 8 & & 0 & 8 & 31 \\
\hline $\begin{array}{l}\text { Valid N } \\
\text { (listwise) }\end{array}$ & 96 & & & & \\
\hline
\end{tabular}

Sumber: Data Diolah

Sebelum melakukan ujian hipotesis, terlebih dahulu dilakukan uji asumsi klasik. Dari hasil uji asumsi klasik diperoleh hasil bahwa Uji Normalitas, Uji Heteroskedastisitas tidak terpenuhi. Setelah ditemukan masalah pada uji asumsi klasik tersebut, maka dilakukan transformasi data dengan menggunakan teknik logaritma (Log) sehingga dapat menyelesaikan masalah normalitas, heteroskedastisitas dan memenuhi syarat pengujian asumsi klasik. Selanjutnya, untuk menguji hipotesis kedua, digunakan data yang telah ditransformasi, dan diperoleh bahwa data yang digunakan untuk uji hipotesis kedua memenuhi syarat pengujian asumsi klasik.

\section{Uji Hipotesis Pertama}

\section{a. Persamaan Regresi Berganda}

Pengujian hipotesis dapat dilakukan setelah diadakan pengujian asumsi klasik. Pengujian hipotesis pertama ini menggunakan analisa regresi linear berganda, dengan cara menguji apakah Profitabilitas, Free Cash Flow, Investment Opportunity Set berpengaruh terhadap Cash Dividend baik secara simultan maupun parsial. Pengaruh yang ditimbulkan ini terlihat pada tabel 4 berikut ini:

Tabel 2

Hasil Analisis Regresi Hipotesis Pertama Unstandardized Coefficients

\begin{tabular}{|c|c|c|}
\hline Model & B & Std. Error \\
\hline 1 (Constant) & 2,218 & 3,829 \\
\hline log_PRO_X1 & 1,345 & ,344 \\
\hline log_FCF_X2 & ,717 & 2,671 \\
\hline log_IOS_X3 & ,081 & ,232 \\
\hline
\end{tabular}

a. Dependen Variabel : $\log _{-} C_{-}$Y

Sumber : Data diolah

Dari tabel 2 maka dapat disusun persamaan regresi berganda sebagai berikut :

Log_CD_Y $=2,218+1,345$ log_PRO_X $X_{1}+0,717$ $\log \_$FCF_X $X_{2}+0,081 \log \_I O S \_X_{3}+e$

Dari model persamaan regresi berganda tersebut bermakna

a) Nilai konstanta sebesar 2,218 yang menunjukkan bahwa apabila semua variabel Profitabilitas, Free cash flow, Investment Opportunity Set diasumsikan bernilai nol, maka nilai dari Cash Dividend adalah sebesar 2,218

b) Profitabilitas berpengaruh positif terhadap Cash Dividend perusahaan manufaktur yang terdapat dalam Bursa Efek Indonesia 2008 2011 dengan nilai koefisien $b_{1}$ sebesar 1,345 artinya jika pertambahan $1 \%$ Profitabilitas akan menambah Cash Dividend sebesar 134,5\%

c) Free Cash Flow berpengaruh positif terhadap Cash Dividend perusahaan manufaktur yang terdapat dalam Bursa Efek Indonesia 2008 2011 dengan nilai koefisien $b_{2}$ sebesar 0,717 artinya jika pertambahan $1 \%$ Free Cash Flow akan menambah Cash Dividend sebesar 71,7 $\%$

d) Investment opportunity Set berpengaruh positif terhadap Cash Dividend perusahaan manufaktur yang terdapat dalam Bursa Efek Indonesia 2008 - 2011 dengan nilai koefisien $\mathrm{b}_{3}$ sebesar 0,081 artinya jika pertambahan $1 \%$ Investment Opportunity Set akan menambah Cash Dividend sebesar 8,1\%

\section{b. Hasil Analisis Koefisien Determinasi $\left(\mathbf{R}^{\mathbf{2}}\right)$}

Pengujian goodness of fit dilakukan unuk menentukan kelayakan suatu model regresi karena variabel penelitian lebih dari dua variabel maka kelayakan tersebut dapat dilihat dari nilai Adjusted $R$ Square. Nilai Adjusted $R$ Square yang diperoleh dari hasil pengolahan data dilihat pada tabel 4 dibawah ini : 
Dari tabel 2 maka dapat disusun persamaan regresi berganda sebagai berikut :

Log_CD_Y $=2,218+1,345 \log \_P R O \_X_{1}+0,717$

log_FCF_X $X_{2}+0,081 \log \_I O S \_X_{3}+e$

Dari model persamaan regresi berganda tersebut bermakna

1) Nilai konstanta sebesar 2,218 yang menunjukkan bahwa apabila semua variabel Profitabilitas, Free cash flow, Investment Opportunity Set diasumsikan bernilai nol, maka nilai dari Cash Dividend adalah sebesar 2,218

2) Profitabilitas berpengaruh positif terhadap Cash Dividend perusahaan manufaktur yang terdapat dalam Bursa Efek Indonesia 2008 - 2011 dengan nilai koefisien $b_{1}$ sebesar 1,345 artinya jika pertambahan $1 \%$ Profitabilitas akan menambah Cash Dividend sebesar 134,5\%

3) Free Cash Flow berpengaruh positif terhadap Cash Dividend perusahaan manufaktur yang terdapat dalam Bursa Efek Indonesia 2008 2011 dengan nilai koefisien $b_{2}$ sebesar 0,717 artinya jika pertambahan $1 \%$ Free Cash Flow akan menambah Cash Dividend sebesar 71,7 \%

4) Investment opportunity Set berpengaruh positif terhadap Cash Dividend perusahaan manufaktur yang terdapat dalam Bursa Efek Indonesia 2008 - 2011 dengan nilai koefisien $b_{3}$ sebesar 0,081 artinya jika pertambahan $1 \%$ Investment Opportunity Set akan menambah Cash Dividend sebesar $8,1 \%$

c. Hasil Analisis Koefisien Determinasi $\left(\mathbf{R}^{\mathbf{2}}\right)$

Pengujian goodness of fit dilakukan unuk menentukan kelayakan suatu model regresi karena variabel penelitian lebih dari dua variabel maka kelayakan tersebut dapat dilihat dari nilai Adjusted $R$ Square. Nilai Adjusted $R$ Square yang diperoleh dari hasil pengolahan data dilihat pada tabel 4 dibawah ini :

Tabel 3

Koefisien Determinasi Hipotesis Pertama

\begin{tabular}{l|l|l|l|l}
\hline Model & $\mathrm{R}$ & $\begin{array}{l}\mathrm{R} \\
\text { Square }\end{array}$ & $\begin{array}{l}\text { Adjusted } \\
\mathrm{R} \text { Square }\end{array}$ & $\begin{array}{l}\text { Std. Error of } \\
\text { the Estimate }\end{array}$ \\
\hline 1 &, $487 \mathrm{a}$ &, 237 &, 212 &, 79654 \\
\hline
\end{tabular}

a. Predictors: (Constant), log_IOS_X3,

log_FCF_X2, log_PRO_X1

b. Dependen Variable: $\log _{-} \mathrm{CD}_{-} \mathrm{Y}$

Sumber: Data Diolah

Tabel 3 memperlihatkan bahwa nilai Adjusted $\mathrm{R}^{2}$ sebesar 0,212 yang berarti bahwa persentase pengaruh variabel independen terhadap Cash Dividend yakni sebesar nilai koefisien determinasi yaitu $21,2 \%$, sedangkan sisanya $78,8 \%$ dipengaruhi atau dijelaskan oleh variabel yang lain yang tidak dimasukkan dalam model penelitian ini.

\section{d. Hasil Uji Simultan (Uji F)}

Pengaruh variabel independen secara simultan terhadap variabel dependen dianalisis dengan menggunakan uji $F$, yaitu dengan memperhatikan tingkat signifikansi nilai $\mathrm{F}$ pada output perhitungan dengan tingkat alpha 5\%. Untuk lebih jelasnya dapat dilihat pada tabel 4 :
Tabel 5 Hasil Regresi Uji F

\begin{tabular}{|c|c|c|c|c|c|c|}
\hline \multicolumn{2}{|c|}{ Model } & \multirow{2}{*}{$\begin{array}{r}\begin{array}{l}\text { Sum of } \\
\text { Squares }\end{array} \\
18,146\end{array}$} & \multirow{2}{*}{$\frac{\text { Df }}{3}$} & \multirow{2}{*}{$\begin{array}{l}\begin{array}{l}\text { Mean } \\
\text { Square }\end{array} \\
6,049\end{array}$} & \multirow{2}{*}{$\frac{F}{9,533}$} & \multirow{2}{*}{$\frac{\text { Sig. }}{, 000^{\mathrm{a}}}$} \\
\hline 1 & $\begin{array}{l}\text { Regress } \\
\text { ion }\end{array}$ & & & & & \\
\hline & $\begin{array}{l}\text { Residu } \\
\text { al }\end{array}$ & 58,372 & 92 & ,634 & & \\
\hline & Total & 76,518 & 95 & & & \\
\hline
\end{tabular}

a. Predictors: (Constant), log_IOS_X3, log_FCF_X2, log_PRO_X1

b. Dependen Variable: $\log _{-} \mathrm{CD}_{-} \mathrm{Y}$

Sumber: Data Diolah

Dari Tabel 4 diperoleh nilai $F_{\text {hitung }}$ sebesar 9,533 sedangkan $\mathrm{F}_{\text {tabel }}$ pada tingkat kepercayaan $\alpha=$ $5 \%$ dengan $\mathrm{df}_{1}=\mathrm{k}-1=2$ dan $\mathrm{df}_{2}=\mathrm{n}-\mathrm{k}-1=95$ $3-1=91$ adalah sebesar 3,10 dengan tingkat signifikansi 0,000 yang lebih kecil dari $0,05(\alpha=$ 0,05) berarti menerima hipotesis $H_{a}$ yang menyatakan bahwa variabel-variabel independen yaitu Profitabilitas, Free Cash Flow dan Investment Opportunity Set secara bersama-sama berpengaruh signifikan terhadap Cash Dividend.

\section{e. Hasil Uji Parsial (Uji t)}

Uji statistik dilakukan untuk menguji pengaruh variabel Profitabilitas, Free Cash Flow dan Investment Opportunity Set terhadap Cash Dividend secara parsial dengan pengujian terlihat pada tabel 5 berikut ini :

Tabel 5

Hasil Regresi Uji t

\begin{tabular}{|c|c|c|c|c|c|}
\hline Model & $\begin{array}{r}\text { Unsta } \\
\mathrm{Z} \\
\text { Coeff } \\
\mathrm{B} \\
\end{array}$ & $\begin{array}{l}\text { hdardi } \\
\text { d } \\
\text { cients } \\
\text { Std. } \\
\text { Error }\end{array}$ & $\begin{array}{c}\text { Standardiz } \\
\text { ed } \\
\text { Coefficien } \\
\text { ts } \\
\text { Beta }\end{array}$ & $\mathrm{t}$ & Sig \\
\hline 1 (Constant) & $\begin{array}{r}2,21 \\
8\end{array}$ & 3,829 & & ,579 & $\begin{array}{r}56 \\
4\end{array}$ \\
\hline $\begin{array}{l}\text { log_PRO_ } \\
\mathrm{X} 1\end{array}$ & $\begin{array}{r}1,34 \\
5\end{array}$ & ,344 & ,448 & $\begin{array}{r}3,90 \\
4\end{array}$ & $\begin{array}{r}, 00 \\
0\end{array}$ \\
\hline $\begin{array}{l}\text { log_FCF_ } \\
\mathrm{X} 2\end{array}$ & ,717 & 2,671 & ,029 & ,268 & $\begin{array}{r}78 \\
9\end{array}$ \\
\hline $\begin{array}{l}\text { log_IOS_ } \\
\text { X3 }\end{array}$ & ,081 & ,232 & ,042 & ,350 & $\begin{array}{r}72 \\
7\end{array}$ \\
\hline
\end{tabular}

Dependen Variabel : log_CD_Y

Sumber: Data Diolah

Kriteria pengambilan keputusan menggunakan taraf nyata $5 \%$ untuk uji dua arah $(\alpha / 2)=0,05 / 20=0,0250$ dengan derajat bebas $(\mathrm{df})=$ $\mathrm{n}-\mathrm{k}=95-3=92$. Nilai $\mathrm{t}$ tabel dengan taraf nyata $\alpha / 2=0,025$ dan $\mathrm{df}=92$ adalah 1,98609

1) Jika $t_{\text {hitung }}>t_{\text {tabel }}(1,98609)$ atau $t_{\text {hitung }}<t_{\text {tabel }}(-$ 1,98609), maka $\mathrm{H}_{\mathrm{a}}$ yang diajukan diterima (berpengaruh)

2) Jika $t_{\text {tabel }}(-1,98609) \leq t_{\text {hitung }} \leq t_{\text {tabel }}(1,98609)$, maka Ha tidak dapat diterima (tidak berpengaruh) 
Berdasarkan hasil pengujian tabel 7, maka secara parsial pengaruh masing-masing variabel independen terhadap variabel dependen dapat diuraikan sebagai berikut :

1) Variabel Profitabilitas mempunyai nilai $t_{\text {hitung }}=$ 3,904 yang lebih besar dari $t_{\text {tabel }}(1,98609)$ dengan tingkat signifikansi sebesar 0,000 yang lebih kecil dari $\alpha=0,05$ sehingga dapat disimpulkan bahwa variabel Profitabilitas berpengaruh positif dan signifikansi terhadap Cash Dividend pada perusahaan manufaktur yang terdaftar di BEI tahun 2008 - 2011. Kondisi ini berarti Hipotesis $\mathrm{H}_{\mathrm{a}}$ diterima.

2) Variabel Free Cash Flow mempunyai nilai $t_{\text {hitung }}$ $=0,268$ yang lebih kecil dari $t_{\text {tabel }}(1,98609)$ dengan tingkat signifikansi sebesar 0,789 yang lebih besar dari $\alpha=0,05$ sehingga dapat disimpulkan bahwa variabel Free Cash Flow tidak berpengaruh terhadap Cash Dividend pada perusahaan manufaktur yang terdaftar di BEI tahun 2008 - 2011. Kondisi ini berarti Hipotesis $\mathrm{H}_{\mathrm{a}}$ tidak dapat diterima.

3) Variabel Investment Opportunity Set mempunyai nilai $t_{\text {hitung }}=0,350$ yang lebih kecil dari $t_{\text {tabel }}$ $(1,98609)$ dengan tingkat signifikansi sebesar 0,727 yang lebih besar dari $\alpha=0,05$ sehingga dapat disimpulkan bahwa variabel Investment Opportunity Set tidak berpengaruh terhadap Cash Dividend pada perusahaan manufaktur yang terdaftar di BEI tahun 2008 - 2011. Kondisi ini berarti Hipotesis $\mathrm{H}_{\mathrm{a}}$ tidak dapat diterima.

\section{Uji Hipotesis Kedua}

Pengujian hipotesis kedua ini menggunakan analisis regresi berganda dengan uji residual, dan variabel moderating berupa Likuiditas. Penggunaan variabel moderating ini dimaksud untuk membuktikan hipotesis bahwa variabel Likuiditas yang diproksikan pada Current Ratio selaku variabel moderating dapat memoderasi hubungan variabel independen Profitabilitas, Free Cash Flow, dan Investment Opportunity Set terhadap Cash Dividend. Hasil persamaan uji residual dalam penelitian ini dapat dilihat pada tabel 6 .

\section{Tabel 7}

Hasil Pengujian Pengaruh Profitabilitas, Free Cash Flow dan Investment Opportunity Set terhadap Likuiditas

\begin{tabular}{|c|c|c|c|c|c|}
\hline \multirow[t]{2}{*}{ Model } & $\begin{array}{l}\text { Unstanc } \\
\text { d Coeff }\end{array}$ & $\begin{array}{l}\text { lardize } \\
\text { icients }\end{array}$ & $\begin{array}{c}\text { Standar } \\
\text { dized } \\
\text { Coeffici } \\
\text { ents } \\
\end{array}$ & \multirow[t]{2}{*}{$\mathrm{t}$} & \multirow[t]{2}{*}{ Sig. } \\
\hline & B & $\begin{array}{l}\text { Std. } \\
\text { Error }\end{array}$ & Beta & & \\
\hline 1 (Constant) & 1,864 & 1,310 & & 1,422 &, 158 \\
\hline $\begin{array}{l}\text { log_PRO_ } \\
\text { X1 }\end{array}$ &, 563 &, 118 & ,570 & 4,768 &, 000 \\
\hline $\begin{array}{l}\log _{\mathrm{X} 2} \mathrm{FCF}_{-} \\
\end{array}$ &,- 648 & ,920 &,- 079 &,- 705 & ,483 \\
\hline $\begin{array}{l}\log \_I O S_{-} \\
\text {X3 }\end{array}$ &,- 301 & ,087 &,- 443 & $-3,452$ &, 001 \\
\hline
\end{tabular}

Sumber: Data Diolah
Model (a) yang dapat dikembangkan dari hasil penelitian hipotesis kedua adalah

$M=1,864+0,563 \log \_P R O \_X 1$ -

0,648log_FCF_X2 - 0,301log_IOS_X3 + e

Dari model diatas dapat disimpulkan bahwa Profitabilitas dan Investment Opportunity Set berpengaruh secara signifikan terhadap variabel moderating (Likuiditas) perbedaannya adalah Profitabilitas berpengaruh positif sedangkan Investment Opportunity set berpengaruh negatif. Hal ini ditunjukkan oleh angka signifikan yang lebih kecil dari 0,05 sedangkan untuk variabel Free Cash Flow tidak berpengaruh secara signifikan terhadap variabel moderating (Likuiditas) karena angka signifikan yang lebih besar dari 0,05.

Model (a) untuk hipotesis kedua bertujuan untuk mendapatkan nilai residual dari variabel moderating. Nilai residual dari model (a) digunakan sebagai variabel independen pada model (b). Dari hasil uji model (b) akan diperoleh kesimpulan apakah variabel Likuiditas bisa dikatakan variabel moderating atau tidak. Sebuah variabel dikatakan sebagai variabel moderating jika memiliki nilai koefisien yang negatif dan berpengaruh signifikan. Hasil pengujian model (b) dapat dilihat pada tabel 7 berikut ini

Tabel 7

Hasil Pengujian Regresi Hipotesis Kedua

\begin{tabular}{|c|c|c|c|c|c|}
\hline \multirow[b]{2}{*}{ Model } & $\begin{array}{l}\text { Unsta } \\
\text { Coef }\end{array}$ & $\begin{array}{l}\text { dardiz } \\
\text { d } \\
\text { cients }\end{array}$ & $\begin{array}{c}\text { Standardiz } \\
\text { ed } \\
\text { Coefficient } \\
\text { s } \\
\end{array}$ & \multirow[b]{2}{*}{$\mathrm{T}$} & \multirow[b]{2}{*}{ Sig } \\
\hline & B & $\begin{array}{l}\text { Std. } \\
\text { Error }\end{array}$ & Beta & & \\
\hline $\begin{array}{l}1 \text { (Constan } \\
\text { t) }\end{array}$ & ,292 & ,038 & & $\begin{array}{r}7,78 \\
2\end{array}$ & $\begin{array}{r}, 00 \\
0\end{array}$ \\
\hline $\begin{array}{l}\log _{-} C_{-} \\
\mathrm{Y}\end{array}$ & , 036 & ,017 &,- 218 & $\begin{array}{r}- \\
2,15 \\
0\end{array}$ & $\begin{array}{r}, 03 \\
4\end{array}$ \\
\hline
\end{tabular}

a. Dependen Variable: abs_res

Sumber: Data Diolah

Dari tabel 7 tersebut, maka model uji residual dapat diformulasikan dalam bentuk persamaan sebagai berikut :

$$
|\mathbf{e}|=0,292-0,036 l o g \_C D \_Y+e
$$

Berdasarkan hasil uji statistik yang dilakukan diketahui bahwa nilai Log_CD_Y signifikan sebesar $0,034<0,05$. Sebuah variabel dikatakan variabel moderating jika memiliki koefisien yang negatif dan berpengaruh signifikan. Dari angka tersebut, dapat disimpulkan bahwa variabel Likuiditas merupakan variabel moderating yang memoderasi hubungan antara Profitabilitas, Free Cash Flow dan Investment Opportunity Set dengan Cash Dividend. 


\section{KESIMPULAN DAN KETERBATASAN} 1. Kesimpulan

a. Profitabilitas, Free Cash Flow dan Investment Opportunity Set secara simultan berpengaruh positif dan signifikan terhadap Cash Dividend pada perusahaan manufaktur yang terdaftar di Bursa Efek Jakarta 2008 - 2011. Hasil penelitian ini konsisten dengan penelitian yang telah dilakukan oleh Suharli (2007) yang mengindikasikan bahwa Profitabilitas, dan Kesempatan Investasi Set secara simultan berpengaruh positif terhadap Kebijakan Dividen tunai.

b. Secara parsial Profitabilitas berpengaruh positif dan signifikan terhadap Cash Dividend yang berarti bahwa semakin besar profitabilitas yang diperoleh perusahaan maka semakin tinggi cash dividend yang akan dibagikan kepada pemegang saham sedangkan Free Cash Flow dan Investment Opportunity set tidak berpengaruh signifikan terhadap Cash Dividend karena jika cash dividend meningkat, makin sedikit dana yang tersedia untuk reinvestasi, sehingga tingkat pertumbuhan yang diharapkan akan rendah untuk masa mendatang. Hasil penelitian ini mendukung penelitian yang dilakukan oleh Suharli (2007), Satmoko (2009) menyimpulkan bahwa secara parsial profitabilitas berpengaruh secara signifikan terhadap dividen kas.

c. Likuiditas dapat digunakan sebagai variabel moderating karena memberikan hasil yang signifikan dalam mempengaruhi profitabilitas, free cash flow dan investment opportunity set tetapi dari ketiga variabel tersebut hanya profitabilitas yang dapat mempengaruhi cash dividend dengan likuiditas sebagai variabel moderating hal ini berarti bahwa perusahaan yang membukukan keuntungan lebih tinggi (profitabilitas tinggi), ditambah likuiditas yang lebih baik, maka semakin besar jumlah cash dividend yang dibagikan, sedangkan jika ada ketidakpastian yang besar dalam ramalan free cash flow dan investment opportunity set maka yang terbaik adalah bersikap konservatif dan menetapkan cash dividend masa berjalan yang rendah. Hasil penelitian ini mendukung penelitian yang dilakukan oleh Suharli (2007) menemukan bahwa kebijakan jumlah dividen perusahaan dipengaruhi oleh profitabilitas dan diperkuat oleh likuditas perusahaan sedangkan investment opportunity set tidak terpengaruh.

\section{Saran}

a. Penelitian selanjutnya dapat menggunakan metode acak seperti Cluster sampling untuk pengambilan sampel penelitian untuk memperoleh sampel yang mampu mencerminkan keseluruhan populasi dan lebih obyektif.

b. Peneliti selanjutnya dapat melakukan penelitian dengan jangka waktu yang lebih panjang untuk memperoleh simpulan yang lebih teruji dengan periode 5-6 tahun.

c. Peneliti selanjutnya dapat menambahkan variabel-variabel independen. Dengan banyaknya jumlah variabel dimasukkan maka akan membuat temuan baru yang lebih baik dan bermanfaat untuk kepentingan perkembangan ilmu pengetahuan.

\section{E. DAFTAR PUSTAKA}

Ang, Robbert, 1997, Buku Pintar : Pasar Modal Indonesia, Indonesia: Mediasoft Indonesia

Brigham \& Houston, 2001, Manajemen Keuangan Buku II Edisi Kedelapan Penerbit Erlangga

Brigham \& Houston, 2006, Fundamentals of Financial Management Dasar Dasar Manajemen Keuangan Buku 1 Edisi 10 Penerbit Salemba Empat

Ghozali, Imam 2005, Aplikasi Analisis Multivariate dengan program SPSS, Edisi 6 Universitas Diponegoro Semarang

Gumanti, Tatang Ary 2011, Manajemen Investasi Konsep, Teori dan Aplikasi Penerbit Mitra Wacana Media, Jember

Idix, www.idx.com, 2014

Jensen, M.C, dan W.H, Meckling, 1976 "The Theory of the Firm :Managerial Behaviour, Agency Cost, and Ownership Structure". Journal of Financial Economic, October, 1976, V. 3, No. 4, pp. 305-360.

Jensen, 1986, "Agency Cost of free Cash Flow, Corporate Finance, and Takeovers" American Economic Review, May 1986, Vol. 76, No. 2, pp. 323-329.

Satmoko Agung, 2009, "Faktor Faktor Yang mempengaruhi Dividen Kas Perusahaan Manufaktur di Bursa Efek Indonesia", Hasil Penelitian Dosen dan Seminar Nasional, Surabaya 30 April 2009.

Stanford, http: www.standford.edu, 2014.

Sugiyono, 2002, Statistika Untuk Penelitian, Alfabeta, Bandung 
